\title{
LUKISAN FAUNA, POLA SEBARAN DAN LANSKAP BUDAYA DI KAWASAN KARS SULAWESI BAGIAN SELATAN
}

\author{
Animal Painting, Distribution Pattern and Cultural Landscape \\ in the Karst Region of Southern Sulawesi
}

\author{
A. Muh. Saiful ${ }^{1}$ dan Basran Burhan ${ }^{2}$ \\ ${ }^{1}$ Mahasiswa Pascasarjana Jurusan Arkeologi, Universitas Gadjah Mada \\ Jl. Nusantara 1, Bulat Sumur, Sleman, Yogyakarta, Indonesia \\ ifulk.fullah@yahoo.co.id \\ ${ }^{2}$ Alumni Jurusan Arkeologi, Universitas Hasanuddin \\ Jl. Perintis Kemerdekaan, km. 10, Makassar, Indonesia \\ basranburhan@gmail.com
}

Naskah diterima: 22/09/2017; direvisi: 11/10-30/11/2017; disetujui: 30/11/2017
Publikasi ejurnal: 12/12/2017

\begin{abstract}
This paper presents a study of the landscape on the site of several caves that have rock art of prehistoric times. Some prehistoric caves in the southern of the Island of Sulawesi, are the cave region with hand stencils and painting animal. This research is focused on painting animal and cultural landscape. The methods used include collecting the result of rock art research in this region, then classifying the type of painting animal and determining the layout of the painting in the map using GIS software. This software is also used to measure both nearest and farest site from the coastal range in Pleistocene times. The results of identification based on the animal painting, cave pattern distribution, and the environment in the past, finally explained that the prehistoric cave region in the Southern part of Sulawesi is a cultural landscape that has been occupied by two different identity groups based on the characters of the paintings.
\end{abstract}

Keyword: Landscape, animal painting, environment.

Abstrak
Tulisan ini menyajikan studi tentang lanskap pada situs gua-gua yang memiliki gambar dari masa prasejarah. Gua-gua prasejarah di bagian selatan Pulau Sulawesi merupakan kawasan gua dengan karakter lukisan telapak tangan dan fauna. Penelitian ini difokuskan pada lukisan fauna dan lanskap budaya. Metode yang digunakan diantaranya mengumpulkan hasil penelitian lukisan di wilayah ini kemudian mengklasifikasi jenis lukisan fauna dan keletakan situs berlukis tersebut dalam peta dengan menggunakan software GIS. Software ini juga digunakan untuk menghitung jarak situs terdekat dan terjauh dengan pantai di masa Pleistosen. Hasil identifikasi berdasarkan lukisan fauna, pola sebaran gua dan lingkungan masa lalu menjelaskan bahwa kawasan gua-gua prasejarah di bagian selatan Sulawesi merupakan lanskap budaya yang telah diokupasi oleh dua kelompok identitas yang berbeda berdasarkan karakter lukisannya.

Kata Kunci: Lanskap, lukisan fauna, lingkungan

\section{PENDAHULUAN}

Lanskap budaya manusia terbangun dengan keberadan pola yang ditemukan berdasarkan material dan cakupan bentang alam. Kehadiran material budaya merupakan wujud adanya aktivitas yang berkaitan dengan subsistensi pada area yang terbatas ataupun tidak terbatas dan berkaitan pula dengan pemukiman. Oleh karena itu lanskap budaya dapat muncul sebagai perpaduan lanskap fisik dan lanskap subsistensipemukiman (Pickering, 1994). Lanskap fisik adalah ruang dan susunan fenomena lingkungan seperti iklim, topografi, hidrologi, geologi, vegetasi, dan fauna, sedangkan lanskap subsistensi-pemukiman adalah ruang dan distribusi temporal okupasi situs, area aktivitas, dan sumber lokal, 
karena itu lanskap budaya didefinisikan sebagai '...material in that comprises such things as settlement and... symbolic in that it has meaning to human' (Norton, 1989 dalam Pickering, 1994; Gosden dan Head, 1994). Simbol dalam hal ini adalah sesuatu yang dapat dimaknai (Ahimsa-Putra, 2013).

Dalam lanskap budaya berbagai fenomena dapat ditemukan dengan mendasarkan pengamatan pada tipe, gaya, dan karakter artefak yang disatukan dengan kedudukan pada ruang atau wilayah. Tipe artefak pada dasarnya menggambarkan ide, mental, image, dan keberadaan pola yang berbeda dapat merepresentasikan suatu kelompok masyarakat (Shanks dan Tilley, 1987). Kesamaan tipe ataupun gaya artefak pada situs-situs yang berbeda dapat menjelaskan adanya interaksi sosial (Shanks dan Tilley, 1992) dan jika sebaliknya berbeda gaya pada situs yang berbeda dapat menunjukkan kelompok yang berbeda (Hodder, 1992 dalam Shanks dan Tilley, 1992). Fenomena demikian terjadi pada beberapa situs, salah satunya adalah di wilayah Vienna Timur. Pada wilayah ini terdapat situs Lo Roc-Aux-Sorciers yang merupakan pendukung kebudayaan Magdalenian Tengah (16500-12000 BP) dengan ciri arkeologis pahatan wajah manusia berasosiasi dengan hewan dibuat dengan cara menampilkan salah satu dimensi anggota tubuh- bentuk menyamping (parietal art) pada dinding gua dan ceruk. Gaya dan asosiasi ini kemudian menghadirkan hubungan dengan situs di tempat lainnya, yaitu La Marche dan $\mathrm{La}$ Fadets yang juga dikenal sebagai pembuat parietal art. Kesamaan gaya itu kemudian menunjukkan suatu identitas budaya, klaim sosial, dan simbol ruang yang merepresentasikan kekuatan bersama (Fuentes, 2017).

Lanskap sebagai identitas ditunjukkan melalui adanya perhatian khusus oleh pembuat yang sangat jelas mengenai aspek sosial dalam suatu lanskap (Bradley, 1993 dalam Ashmore dan Knapp,
1999). Perhatian khusus tersebut adalah penanda berupa artefak (Knapp dan Ashmore, 1999). Lokasi yang menunjukkan adanya penanda yang sangat menonjol dan memiliki isyarat peristiwa penting di masa lalu dengan mempertimbangkan zona ekologi (Knapp dan Ashmore, 1999) maka tempat tersebut dapat mewujudkan identitas sosial, kekuatan atau identitas pribadi (Ucko, 1994 dalam Knapp dan Ashmore, 1999), disamping itu identitas dapat mewujud karena adanya perbedaan skala status dan atribut budaya yang dihubungkan dengan pola material dalam skala lanskap yang berbeda (Kaelhofer, 2000). Oleh karena itu identitas didefinisikan sebagai kumpulan individu yang memiliki simbol yang kemudian membedakannya dengan kumpulan individu lainnya (Goodenough, 1976 dalam Ahimsa-Putra, 2013). Dengan demikian ciri identitas sosial yang tersebar dalam suatu bentang alam dapat dipahami sebagai lanskap identitas sosial.

Berdasar dari penjelasan di atas, maka keberadaan sebaran lukisan pada suatu kawasan memungkinkan dapat menjelaskan kehadiran suatu identitas sosial masyarakat di masa lalu. Lukisan pertamakali muncul pada periode Pleistosen Akhir di dindingdinding dan langit-langit gua yang dijadikan sebagai hunian pada saat itu. lukisan tersebut merepresentasikan bentuk aktifitas umum dalam kehidupan manusia (Terzi, 1992), berkaitan dengan pola diet atau subsistensi (Ripoll dan Munoz, 2007) dan merepresentasikan hal-hal yang berkaitan dengan kegaiban atau upacara tertentu seperti kelahiran, kematian, kesuburan atau bentuk yang memiliki kekuatan tertentu (Terzi, 1992). Pada umumnya gua-gua hadir dalam jumlah yang banyak di suatu gugusan atau kawasan kars, gua tersebut tersebar mengikuti pola keberadaan kars dan tak jarang manusia mengokupasinya secara intens. Bukti okupasi berupa tinggalan arkeologis yang tersebar pada area luas dapat menunjukkan adanya lanLandsskap budaya. Terminologi lanskap budaya 
mengacu pada adanya pengaruh yang intens atau tidak intens dari manusia terhadap alam yang dapat diamati melalui keberadaan pola (Kuster, 2004). Berdasarkan pada terminologi tersebut, maka kehadiran lukisan pada sebaran gua-gua di suatu kawasan kars mencerminkan adanya lanskap budaya.

Oleh karena itu keberadaan gugusan kars dan gua-gua yang merupakan okupasi manusia di masa lalu di wilayah bagian selatan Pulau Sulawesi dapat disebut sebagai lanskap budaya. Gua-gua prasejarah tersebut tersebar dari utara hingga ke selatan yang tercakup dalam wilayah administrasi Kabupaten Pangkep dan Maros. Karaktersitik budaya gua tersebut ditandai dengan keberadaan lukisan telapak tangan dan lukisan fauna serta beberapa lukisan antropomorfis. Hasil penanggalan lukisan yang dilakukan oleh Aubert, dkk., (2014) terhadap 14 gua di bagian selatan memiliki usia 22,9 kyr sampai 39,9 kyr. Penanggalan tersebut memberikan pemahaman bahwa okupasi gua dan terciptanya lukisan tersebut terjadi pada masa Pleitosen Akhir dan kehadirannya berimplikasi pada pengetahuan awal dilakukannya tradisi simbol (Aubert, dkk., 2014) melalui gambar.

Masalah yang kemudian muncul pada lanskap budaya di wilayah ini adalah apakah sebaran keseluruhan gua okupasi tersebut merupakan jejak kelompok yang sama atau berbeda? buatan manusia yang sama atau berbeda?. Tampaknya masalah yang kedua masih terlalu rumit untuk dipecahkan, hal ini dikarenakan sejak dilakukannya penelitian dari tahun 1902 sampai saat ini, belum satupun ditemukan rangka hominid yang berasal dari kawasan kars di bagian utara dan selatan pada wilayah ini. Berbeda dengan masalah yang pertama, melalui identifikasi lukisan dan pola sebaran tampaknya masalah ini dapat terjawab. Optimisme ini muncul karena dalam sepuluh tahun belakangan ini eksplorasi dan identifikasi lukisan sangat rutin dilakukan oleh para peneliti profesional dan mahasiswa. Sekiranya dengan mengumpulkan data hasil penelitian tersebut tidak menutup kemungkinan dapat mengungkap kelompok sosial yang telah mengokupasi wilayah kars tersebut yang berarti kelompok dengan identitas sosial yang berbeda.

Beranjak dari dialektika di atas, pada kesempatan ini penulis akan melakukan penelitian lanskap budaya dengan mengandalkan sebaran gua lukisan fauna dengan tujuan menjelaskan bahwa terdapat kelompok sosial yang berbeda telah mendiami wilayah kars tersebut dan perbedaan tersebut direpresentasikan dengan penanda sebagai identitas sosial pada wilayah yang berbeda.

\section{METODE PENELITIAN}

Perolehan data penelitian dilakukan dengan cara mengumpulkan sumber pustaka yang terkait dengan hasil penelitian lukisan dan penelitian gua prasejarah di kawasan kars bagian selatan Pulau Sulawesi. Sumber pustaka tersebut berupa laporan survey, karya ilmiah yang terdiri atas Disertasi, Tesis, dan Skripsi. Setelah data tersebut terkumpul, identifikasi dilakukan dengan memfokuskan pada jenis lukisan kemudian mengelompokkannya dalam tabel. Selanjutnya pengamatan difokuskan pada lukisan fauna dengan melihat persamaan dan perbedaan fauna tersebut. Lukisan fauna yang telah diidentifikasi sampai tingkat penamaan hewan hingga tingkat spesies yang dihasilkan dari sumber pustaka penulis langsung menggunakannya apabila data tersebut cukup meyakinkan, namun apa bila masih meragukan penulis melakukan identifikasi ulang dengan menggunakan metode perbandingan terhadap fauna yang ada sekarang. Untuk penyebutan fauna, penulis menggunakan nama umum yang dikenal oleh masyarakat (folk taxonomi), hal ini dilakukan untuk memudahkan dalam pemahaman bersama. Seperti misalnya dalam sumber pustaka hasil identifikasi lukisan menyebut hewan "Sus celebensis 
$s p$ ", maka penulis hanya menggunakan penyebutan "babi" demikian juga dengan hewan lainnya.

Metode berikutnya adalah menuangkan data tersebut pada peta. Data geografi yang dimiliki oleh tiap situs yang telah didentifikasi diolah pada komputer dengan menggunakan aplikasi Global Information System (GIS). Tipe lukisan fauna yang serupa diberi tanda yang seragam pada letak geografisnya. Dengan model penanda seperti itu, nantinya akan memunculkan pola apakah tipe lukisan fauna yang sama tersebar-teracak atau tersebar-terkonsentrasi dalam wilayah tertentu. Peta yang digunakan adalah peta 2 dimensi dan 3 dimensi. Penggunaan peta 2 dimensi bertujuan meihat sebaran situs yang memiliki lukisan fauna secara keseluruhan berdasarkan hasil identifikasi, sedangkan peta 3 dimensi bertujuan untuk merekonstruksi lingkungan masa lalu.

Setelah identifikasi lukisan dan identifikasi pada peta dilaksanakan, selanjutnya melakukan eksplanasi dengan mencoba berada pada jalur kerangka konseptual lanskap arkeologi yang berkaitan dengan identitas sosial. Agar tetap berada pada jalur tersebut, maka pertimbanganpertimbangan eksplanasi harus berdasar pada hasil identifikasi lanskap budaya meliputi bentang alam dan tinggalan arkeologi, kemunculan pola, serta syarat suatu tinggalan arkeologi dapat merepresentasikan suatu identitas, khusunya identitas sosial.

\section{HASIL DAN PEMBAHASAN \\ 1. Lokasi dan Data Penelitian}

Lokasi penelitian terletak di bagian selatan Pulau Sulawesi, yaitu wilayah Pantai Barat (Selat Makassar). Wilayah ini berupa gugusan kars Formasi Tonasa yang memanjang utara-selatan dan melebar barattimur (hingga bagian tengah daratan sulawesi bagian selatan) dengan luas \pm 30.000 hektar. Secara administrasi lokasi penelitian berada di wilayah Kabupaten Pangkep dan Kabupaten Maros. Dalam penelitian ini terminologi penyebutan

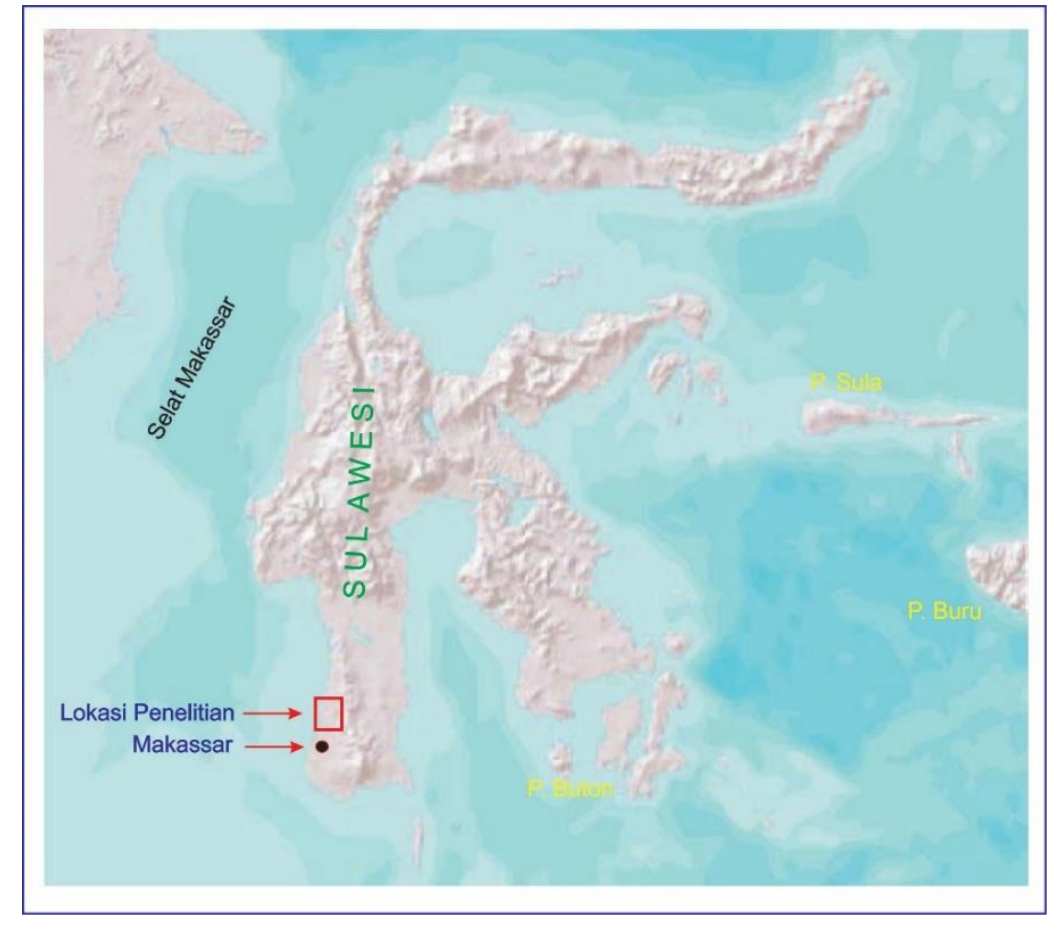

Gambar 1. Peta wilayah penelitian

(Sumber: peta Aubert et al., Tahun 2014, dimodifikasi oleh A. Muh. Saiful) 

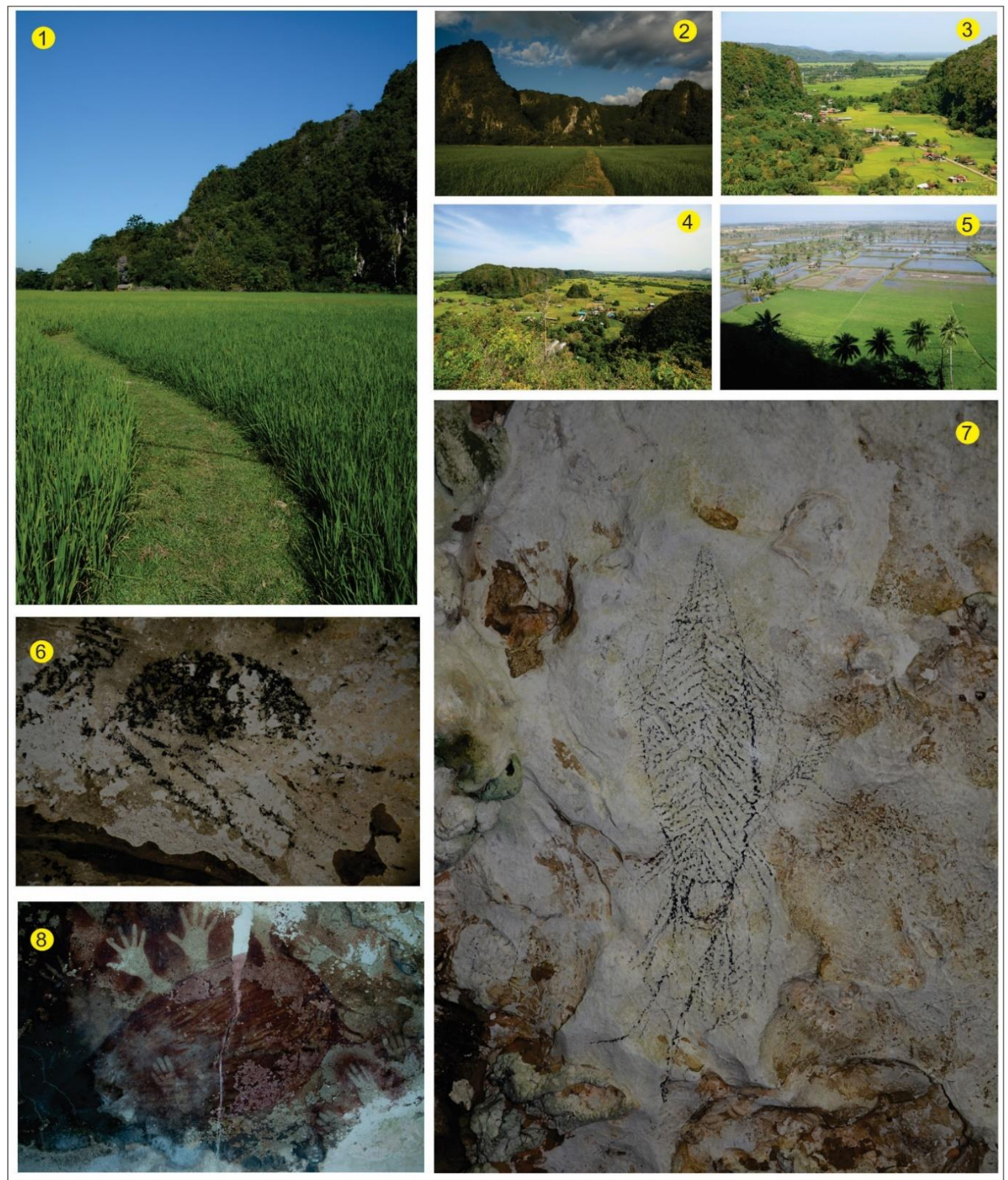

Gambar 2. 1) Situs Leang Timpuseng di wilayah selatan; 2), 3), 4) Lanskap kars wilayah selatan; 5) Lanskap wilayah utara; 6), 7), 8) Lukisan fauna

(Sumber: A. Muh. Saiful tahun, Tahun 2015 \& David McGahan, Tahun 2015)

tempat merujuk pada penyebutann arah mata angin-utara, timur, selatan dan barat. Terminologi ini digunakan untuk memudahkan memahami secara lokasional agar tidak terjebak pada terminologi administrasi dalam merekonstruksi masa lalu.

Kondisi lingkungan pada wilayah kars saat ini, baik di utara maupun di selatan merupakan hamparan dataran rendah dan 
bukit-bukit kapur berbentuk menara dan berdinding terjal dengan ketinggian antara 150- 300 meter. Pada beberapa lokasi khususnya di wilayah-wilayah lembah terdapat menara-menara batu gamping dengan ketinggian kurang $20 \mathrm{~m}$. Selain itu juga, di lembah-lembah kars tersebut mengalir beberapa sungai utama seperti Sungai Pangkajene di sisi paling utara, Sungai Kalibone yang masih terletak dalam wilayah administrasi Kabupaten Pangkep, Sungai Leang-Leang, Sungai Tanralili dan Pattunuang Asue yang berada di sisi paling selatan kawasan kars. Bentuk bentang alam kars yang terlihat seperti sekarang di kawasan ini tidak bisa dilepaskan dari aliranaliran sungai utama tersebut.

Lembah-lembah bukit-bukit kars tersebut juga merupakan dataran yang ditumbuhi berbagai jenis tumbuhan Sida spp, Hyptys spp, Stachytarpheta jamaicensis dan Agatum conyseides, sedang dibagian tepi hutan dijumpai jenis-jenis Macaranga tanarius, Trema orientalis dan Mallotus spp, Caryota mitis (inru), Pterosperum javanisum (bayur), Pinnata (matoa), Leea indica (mali-mali) dan Phytocrene bracteata (tumbuhan merambat), Arenga pinnata (areng). Untuk tipe tumbuhan karang, diantaranya Calcicole, jenis-jenis tumbuhan perdu dari suku Eupatorium dan Lantana camara.

Fauna endemik yang hidup pada kawasan ini di antaranya Monyet dare (Macaca maura), Kuskus beruang
(Ailorups ursinus), Kuskus Sulawesi (Strigocuscus celebensis), Musang Sulawesi (Macrogalidia musschenbroekii schlegel), Musang luwak (Paradoxurus hermaphroditus pallas), Babi hutan Sulawesi (Sus celebensis), Rusa (Cervus timorensis), Tarsius (Tarsius tarsier), dan Tikus (Rattus) (BTNBB, 2011).

Dalam wilayah kars jumlah situs gua yang telah diidentifikasi sebanyak 77 . Jumlah tersebut kemudian diklasifikasi berdasarkan situs yang memiliki lukisan fauna, akhirnya menghasilkan jumlah sebanyak 26 situs yang tersebar secara merata di wilayah utara dan selatan. Gua-gua yang memiliki lukisan fauna sebagian berasosiasi dengan telapak tangan, geometris, dan antropomorfis. Adapun jenis fauna yang berhasil diidentifikasi secara umum adalah babi/babirusa, anoa, burung, ikan-ikan paus, ubur-ubur, penyu/kura-kura, teripang (Handayani, 2015; Pasaribu, 2016).

\section{Karakter Fauna dan Pola Sebarannya}

Setelah mengumpulkan sumber pustaka terkait dengan hasil penelitian lukisan yang telah berlangsung selama10 tahun belakangan ini, akhirnya melalui pengamatan dan proses analisis ditemukan dua kelompok fauna yang digambarkan berdasarkan habitatnya, yaitu fauna aquatik dan fauna terestrial. Jenis fauna aquatik yang ditemukan terdiri atas ikan, penyu, teripang,
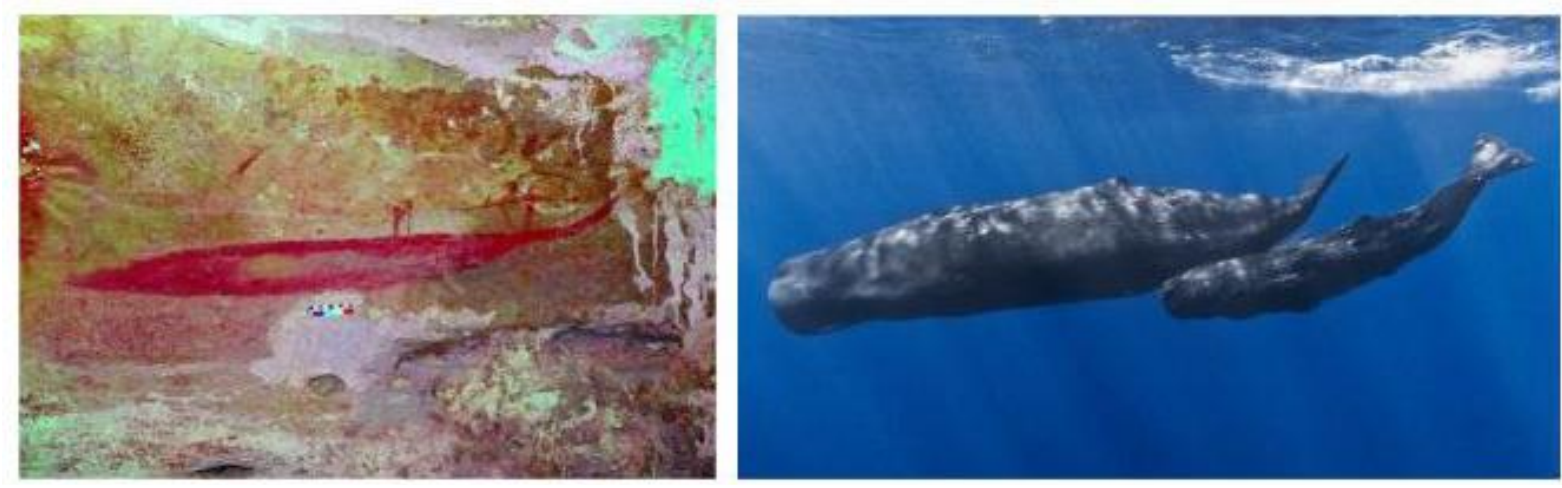

Gambar 3. Lukisan fauna Leang Bulu Sipong, fauna ikan paus

(Sumber: Joshua Pasaribu, Tahun 2016) 

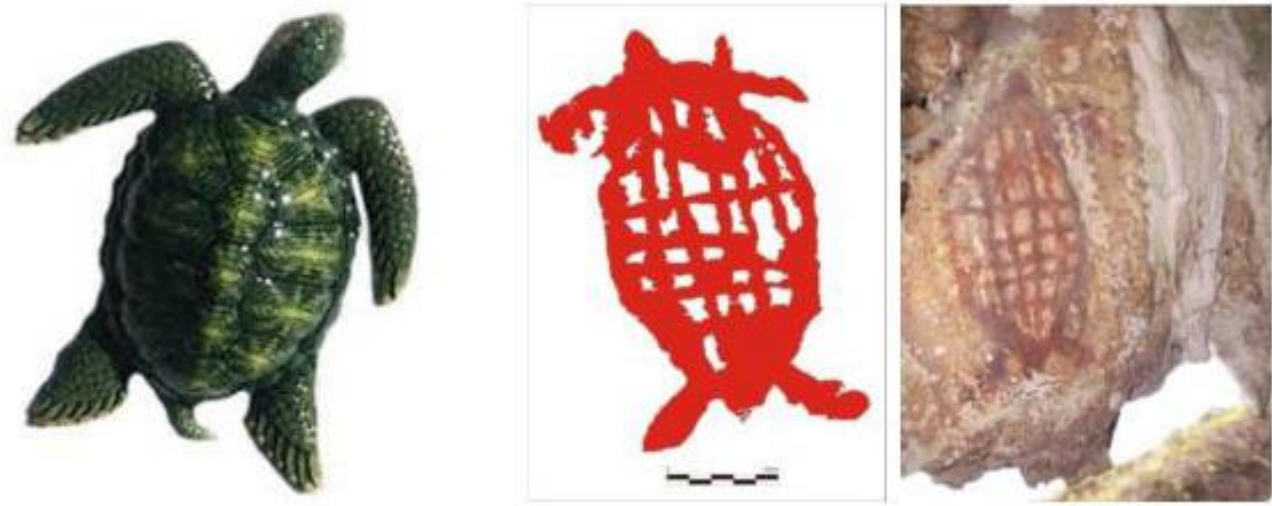

Gambar 4. Lukisan fauna Leang Bulu Bellang, fauna penyu

(Sumber: Andi Sultra Handayani, Tahun 2015)
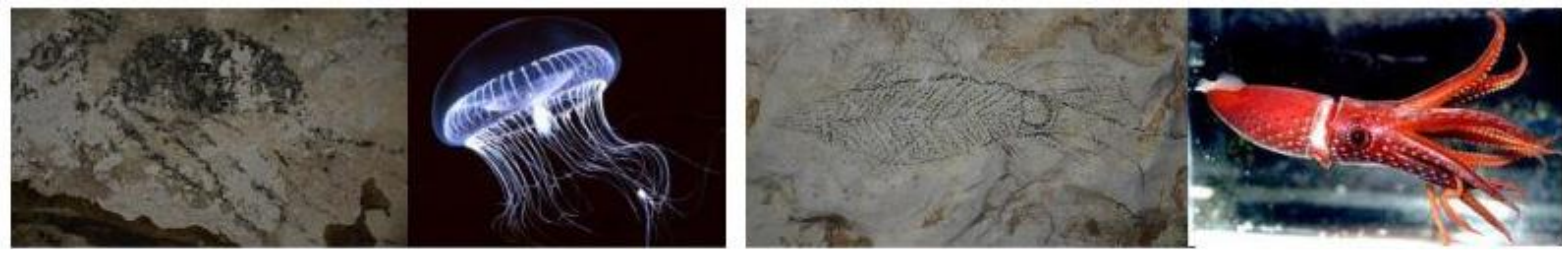

Gambar 5. Kiri; Lukisan fauna Leang Batu Tianang, fauna ubur-ubur. Kanan; Lukisan Leang Karama, fauna cumi-cumi

(Sumber: A. Muh. Saiful, Tahun 2017)
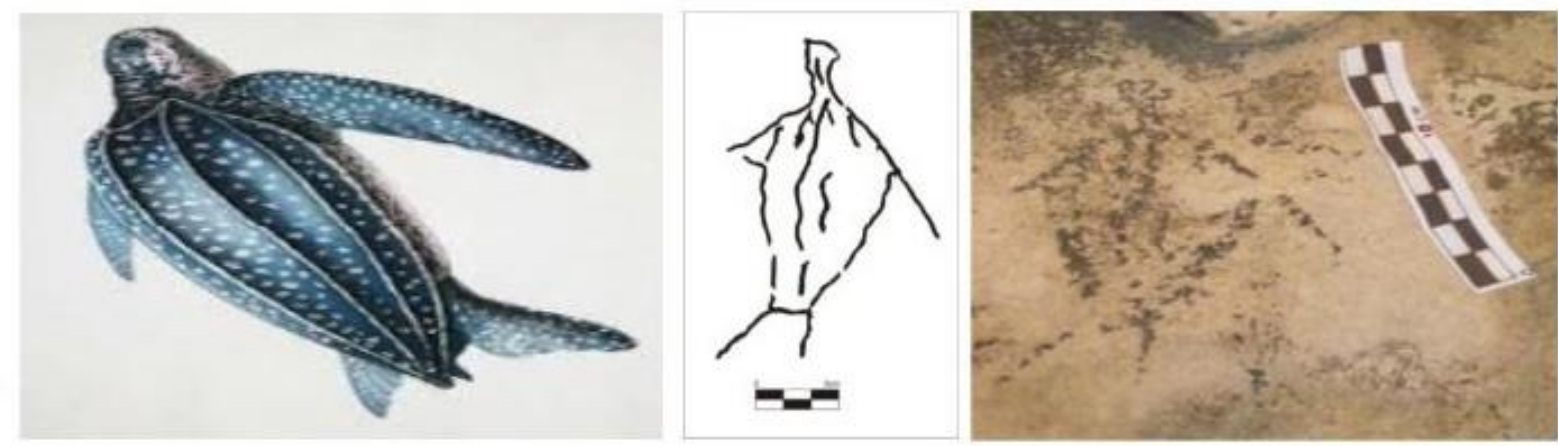

Gambar 6. Lukisan fauna Leang Caddia, fauna penyu

(Sumber: Andi Sultra Handayani, Tahun 2015)

ikan paus, cumi-cumi, dan ubur-ubur, sedangkan fauna terestrial terdiri atas babi, anoa dan burung (lihat gambar 3-11).

Berdasarkan pola sebarannya, kelompok fauna aquatik tersebar di kawasan kars bagian utara sedangkan fauna terestrial tersebar di kawasan kars bagian selatan. 26 situs yang telah dianalisis sebanyak 14 situs memiliki lukisan fauna aquatik, 11 situs memiliki lukisan fauna terestrial, dan 1 situs memiliki lukisan aquatik dan terestrial. Perbedaan jenis lukisan dan perbedaan wilayah terkonsentrasinya sebaran lukisan tersebut merepresentasikan ciri pembeda yang merupakan syarat terminologi identitas.

Perbedaan wilayah tersebut kemudian diikuti dengan perbedaan penggunaan gua-gua kars, situs di wilayah utara memanfaatkan gua yang berada pada gugusan kars yang cenderung lebih kecil dan berdiri sendiri, sedangkan di wilayah selatan gua yang dimanfaatkan cenderung gua yang berada pada gugusan kars yang lebih besar. 
Di wilayah utara gua tersebut adalah gua nomor 1-5, 11, 12, 14 (lihat gambar 12 dan 14) yang berada pada gugasan kars terluarberdiri sendiri. Di wilayah selatan terdapat 4 situs yang berada pada gugusan kars yang berdiri sendiri, sisanya sebanyak 7 gua berada pada gugusan kars besar, bahkan terdapat satu situs berada di tengah-tengah bukit kars, yaitu gua no 17 (lihat gambar 12 dan 14). Meskipun di wilayah utara terdapat 2 situs terestrial tetapi secara lokasional situs tersebut berada di sebelah timur sebaran situs aquatik, situs ini terletak di gugusan kars besar. Dengan keberadan dua situs terestrial di wilayah utara menjelaskan secara rinci bahwa mereka cenderung mencari situs yang berada pada gugusan kars besar dimana di dalam gugusan tersebut
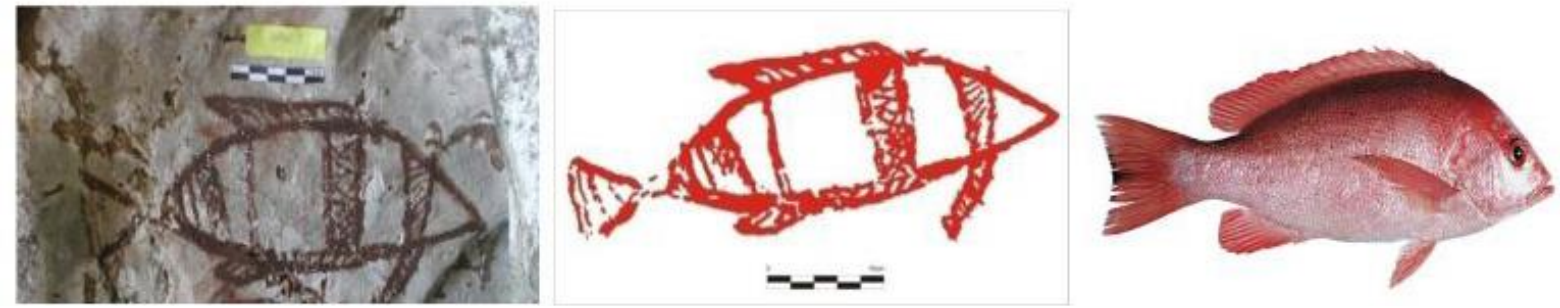

Gambar 7. Lukisan fauna Leang Lasitae, fauna ikan

(Sumber: Andi Sultra Handayani, Tahun 2015)
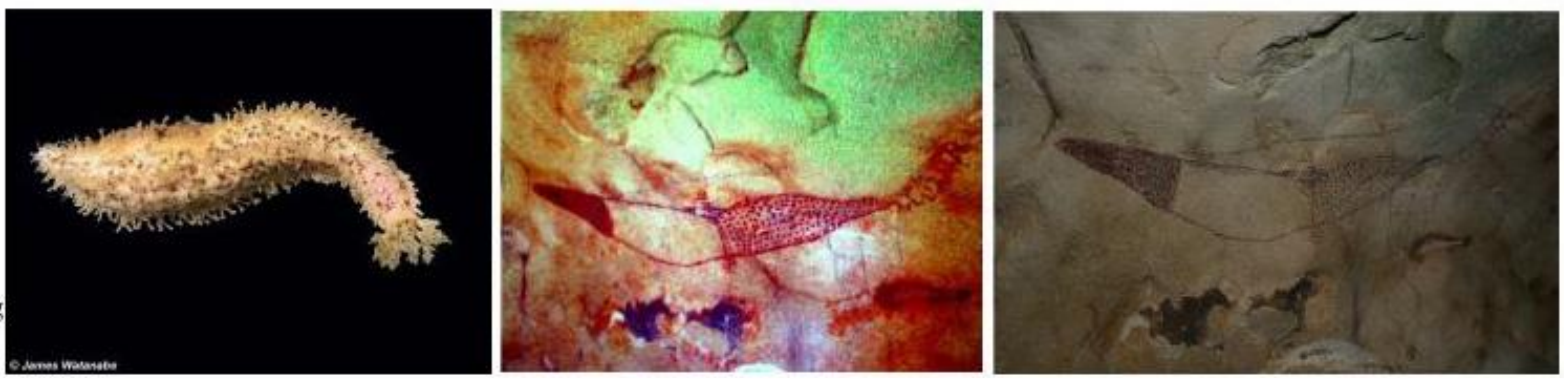

Gambar 8. Lukisan Leang Batu Tianang, fauna teripang

(Sumber: Joshua Pasaribu, 2016 dan A. Muh. Saiful, Tahun 2017)
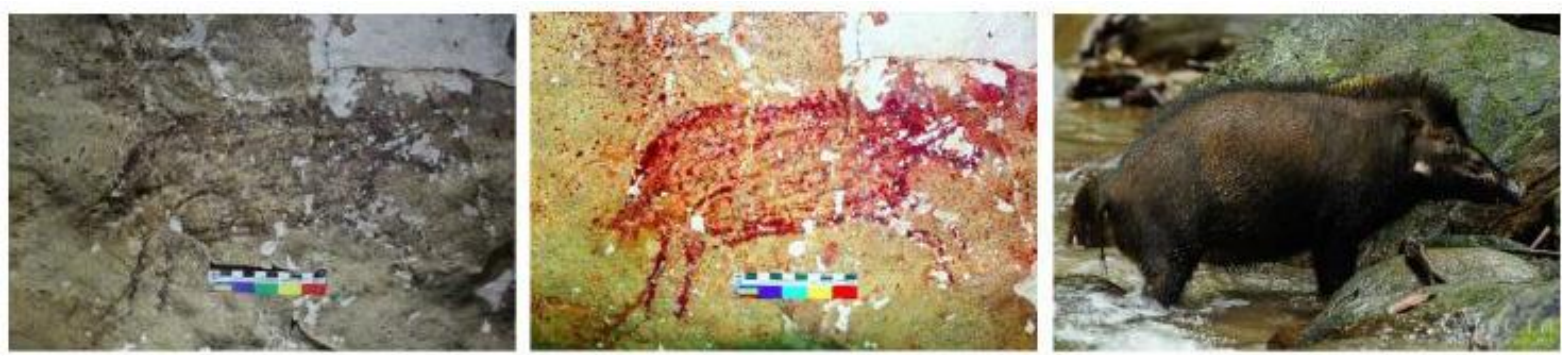

Gambar 9. Lukisan Leang Petta, fauna babi

(Sumber: Joshua Pasaribu, Tahun 2016)
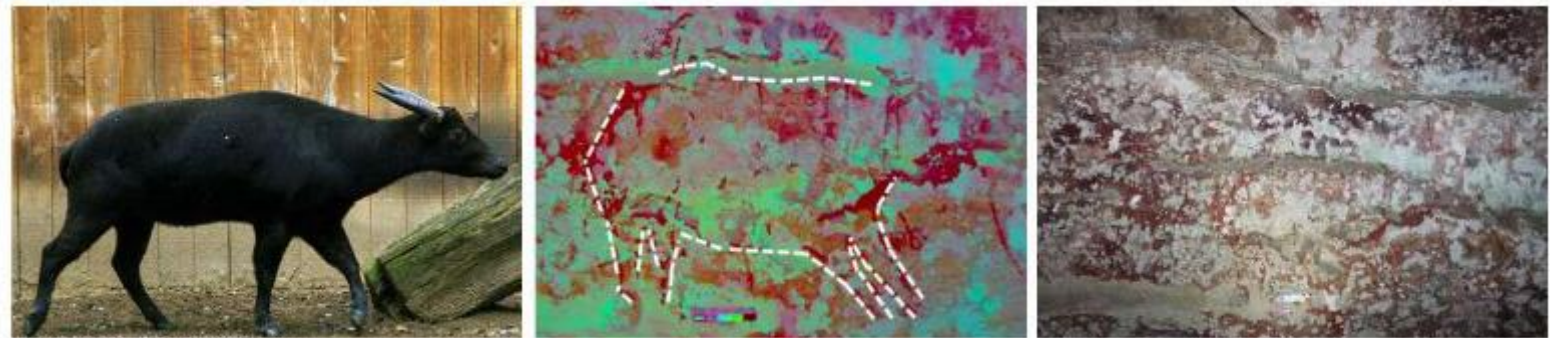

Gambar 10. Lukisan Leang Jing, fauna Anoa

(Sumber: Joshua Pasaribu, Tahun 2016) 

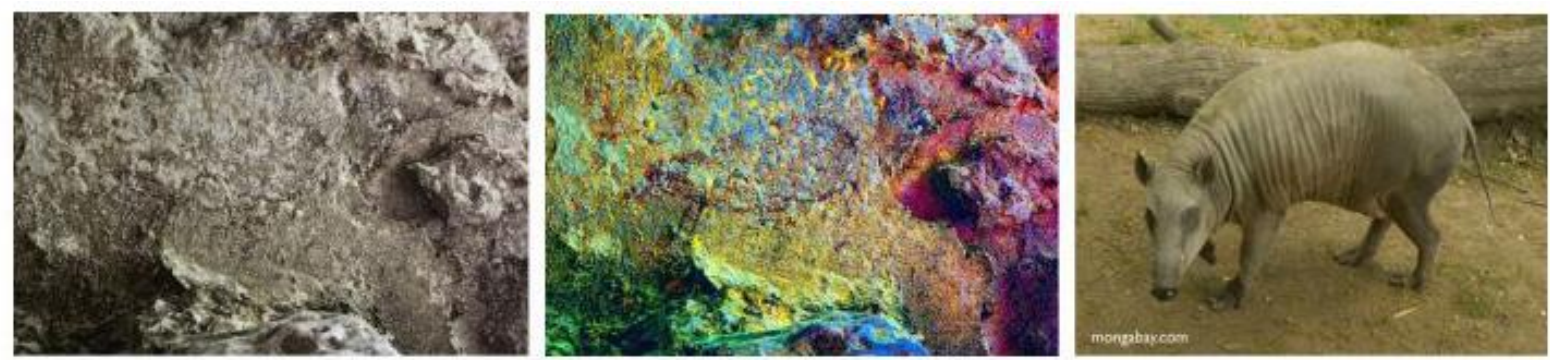

Gambar 11. Lukisan Leang Timpuseng, fauna babi

(Sumber: Joshua Pasaribu, Tahun 2016)

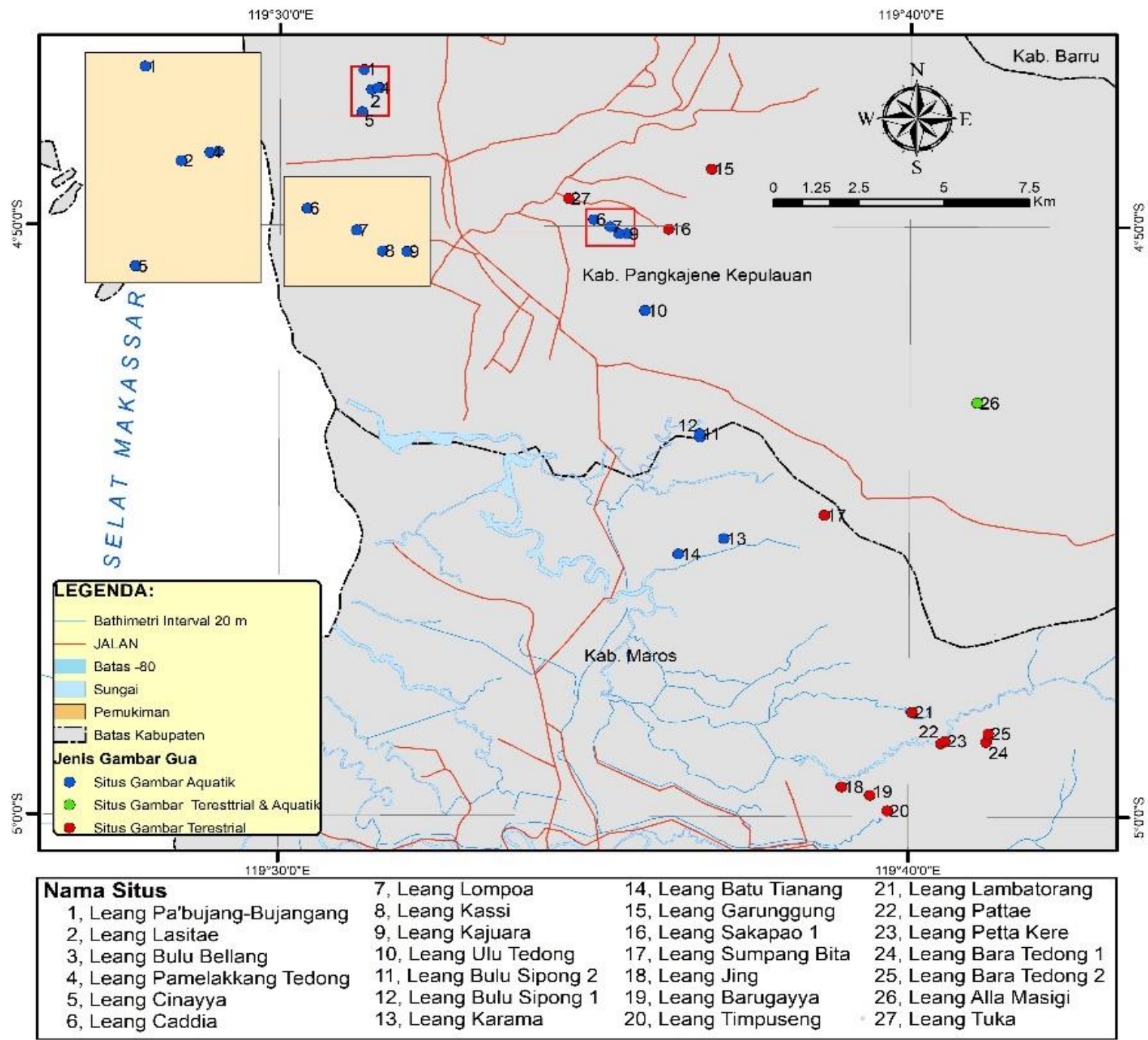

Gambar 12. Sebaran situs gua lukisan fauna

(Sumber: BPCB Sul-Sel dan vektor Indonesia slakala 1: 250.000, dimodifikasi oleh Basran Burhan, Tahun 2017)

merupakan habitat fauna terestrial. Oleh karena itu mereka menempati situs yang berhubungan dengan akses yang lebih dekat dengan hutan atau habitat terestrial.
Munculnya sebaran situs yang terkonsentrasi-menyebar pada wilayah utara (lukisan aquatik) dan selatan (lukisan terestrial) mengindikasikan kehadiran 
Tabel 1. Data Situs dan temuan gambar fauna Aquatik serta asosiasinya dengan gambar lain

\begin{tabular}{|c|c|c|c|c|c|c|c|c|c|c|c|}
\hline \multirow[b]{2}{*}{ No } & \multirow[b]{2}{*}{ Situs } & \multicolumn{6}{|c|}{ Karakter gambar Fauna } & \multicolumn{3}{|c|}{ Asosiasi } & \multirow[b]{2}{*}{ Geometris } \\
\hline & & Ikan & $\begin{array}{l}\text { Ubur- } \\
\text { Ubur }\end{array}$ & Teripang & Penyu & $\begin{array}{l}\text { Cumi- } \\
\text { Cumi }\end{array}$ & $\begin{array}{l}\text { Ikan } \\
\text { Paus }\end{array}$ & Antropomorfis & Perahu & $\begin{array}{c}\text { Telapak } \\
\text { Tangan }\end{array}$ & \\
\hline 1 & Leang Caddia & $\sqrt{ }$ & & & $\sqrt{ }$ & & & & & $\sqrt{ }$ & \\
\hline 2 & Leang Lompoa & $\sqrt{ }$ & & $\sqrt{ }$ & & & & & & $\sqrt{ }$ & \\
\hline 3 & Leang Kajuara & $\sqrt{ }$ & & & & & & & & $\sqrt{ }$ & \\
\hline 4 & Karama & $\sqrt{ }$ & $\sqrt{ }$ & & & $\sqrt{ }$ & & & & $\sqrt{ }$ & \\
\hline 5 & Batu Tianang & $\sqrt{ }$ & $\sqrt{ }$ & $\sqrt{ }$ & & & & $\sqrt{ }$ & $\sqrt{ }$ & & \\
\hline 6 & Bulu Sipong 1 & $\sqrt{ }$ & & & & & $\sqrt{ }$ & & & & \\
\hline 7 & Bulu Sipong 2 & $\sqrt{ }$ & & & & & & & & $\sqrt{ }$ & \\
\hline 8 & Leang Ulu Tedong & $\sqrt{ }$ & & & $\sqrt{ }$ & & & $\sqrt{ }$ & & & \\
\hline 9 & leang lasitae & $\sqrt{ }$ & & $\sqrt{ }$ & & & & & & & \\
\hline 10 & Leang Pame. Tedong & $\sqrt{ }$ & $\sqrt{ }$ & & & & & & & & $\sqrt{ }$ \\
\hline 11 & Leang Bulu Bellang & $\sqrt{ }$ & & & $\sqrt{ }$ & & & & & & \\
\hline 12 & Leang Kassi & $\sqrt{ }$ & & & & & & $\sqrt{ }$ & & & \\
\hline 13 & Leang Pabujangbujangang & $\sqrt{ }$ & & & & & & & & & \\
\hline 14 & Leang Cinayya & $\sqrt{ }$ & & & & & & & & & \\
\hline
\end{tabular}

Tabel 2. Data Situs dan temuan gambar Fauna Terestrial serta asosiasinya dengan gambar lain

\begin{tabular}{|c|c|c|c|c|c|}
\hline \multirow{2}{*}{ No } & \multirow{2}{*}{ Situs } & \multicolumn{3}{|c|}{$\begin{array}{c}\text { Karakter Gambar } \\
\text { Fauna }\end{array}$} & \multirow{2}{*}{$\begin{array}{c}\text { Asosiasi } \\
\text { Telapak } \\
\text { Tangan }\end{array}$} \\
\hline & & Babi & Anoa & Burung & \\
\hline 1 & Leang Pettae & $\sqrt{ }$ & & & $\sqrt{ }$ \\
\hline 2 & Leang Petta Kere & $\sqrt{ }$ & & & $\sqrt{ }$ \\
\hline 3 & Bara Tedong & $\sqrt{ }$ & & & $\sqrt{ }$ \\
\hline 4 & Leang Jing & $\sqrt{ }$ & $\sqrt{ }$ & $\sqrt{ }$ & \\
\hline 5 & Leang Timpuseng & $\sqrt{ }$ & & & $\sqrt{ }$ \\
\hline 6 & Leang Barugayya & $\sqrt{ }$ & & & \\
\hline 7 & Leang Lambatorang & $\sqrt{ }$ & & & \\
\hline 8 & Leang Tuka & $\sqrt{ }$ & & & \\
\hline 9 & Leang Sakapao & $\sqrt{ }$ & & & $\sqrt{ }$ \\
\hline 10 & Leang Garunggung & $\sqrt{ }$ & & & $\sqrt{ }$ \\
\hline 11 & Leang Sumpang Bita & $\sqrt{ }$ & $\sqrt{ }$ & & $\sqrt{ }$ \\
\hline
\end{tabular}

lanskap yang dimaknai oleh para kelompok penghuni gua tersebut. Lanskap tersebut semakin jelas ketika melihat bagaimana mereka menempati gua-gua yang tersedia. kelompok aquatik cenderung menggunakan gua dengan gugusan kars yang kecilterpisah, dimana gugusan tersebut berada pada bagian luar gugusan kars besar dan lebih ke barat. Wilayah yang lebih ke barat berarti wilayah yang jaraknya akan lebih dekat dengan pantai. Sedangkan kelompok terestrial cenderung menggunakan gua yang berada pada gugusan kars yang besar-habitat terestrial. Maka dari itu, dengan pertimbangan lukisan, wilayah sebaran, serta penggunaan gua akhirnya ciri yang ditemukan tersebut merepresentasikan adanya simbol lanskap sebagai perwujudan identitas yang bersifat sosial.
Perbedaan yang diuraikan di atas pada akhirnya memperlihatkan bahwa kelompok ini memiliki cara hidup yang berbeda. Kelompok di wilayah utara menjelaskan kehidupan yang identik dengan maritim/laut sedangkan kelompok di wilayah selatan identik dengan kehidupan daratan/pedalaman/hutan.

\section{Lingkungan Masa Lalu}

Jika mengamati kondisi lingkungan di masa Plesitosen Akhir, pada wilayah kars sebaran lukisan dengan penanggalan yang telah ada, yaitu 39.9 kyr-22,9 kyr, maka wilayah daratan yang mengarah ke pantai barat (Selat Makassar) merupakan daratan landai dan luas karena pada masa tersebut air laut turun hingga mencapai 80 meter (Bellwood, 2007) (lihat gambar 5). Jarak terdekat situs di wilayah utara dengan pantai pada masa Pleistosen Akhir 48,9 km sedangkan jarak situs terjauh $52,5 \mathrm{~km}$. Di wilayah selatan, jarak situs terdekat dengan pantai $50,7 \mathrm{~km}$ dan jarak situs terjauh 55,5 $\mathrm{km}$. Perbedaan antara jarak situs terdekat di kedua wilayah tersebut tidak memiliki perbedaan yang signifikan, sehingga kelompok di wilayah selatan seharusnya dapat juga mencapai pantai.

Pada masa Pleistosen Akhir, daratan pada wilayah utara dan selatan mengikuti kondisi iklim yang terjadi secara global, yaitu iklim glasiasi yang terjadi secara fluktuatif, akhir glasiasi ini berakhir di masa 18,000 BP (Bellwood, 2007). Pada masa 


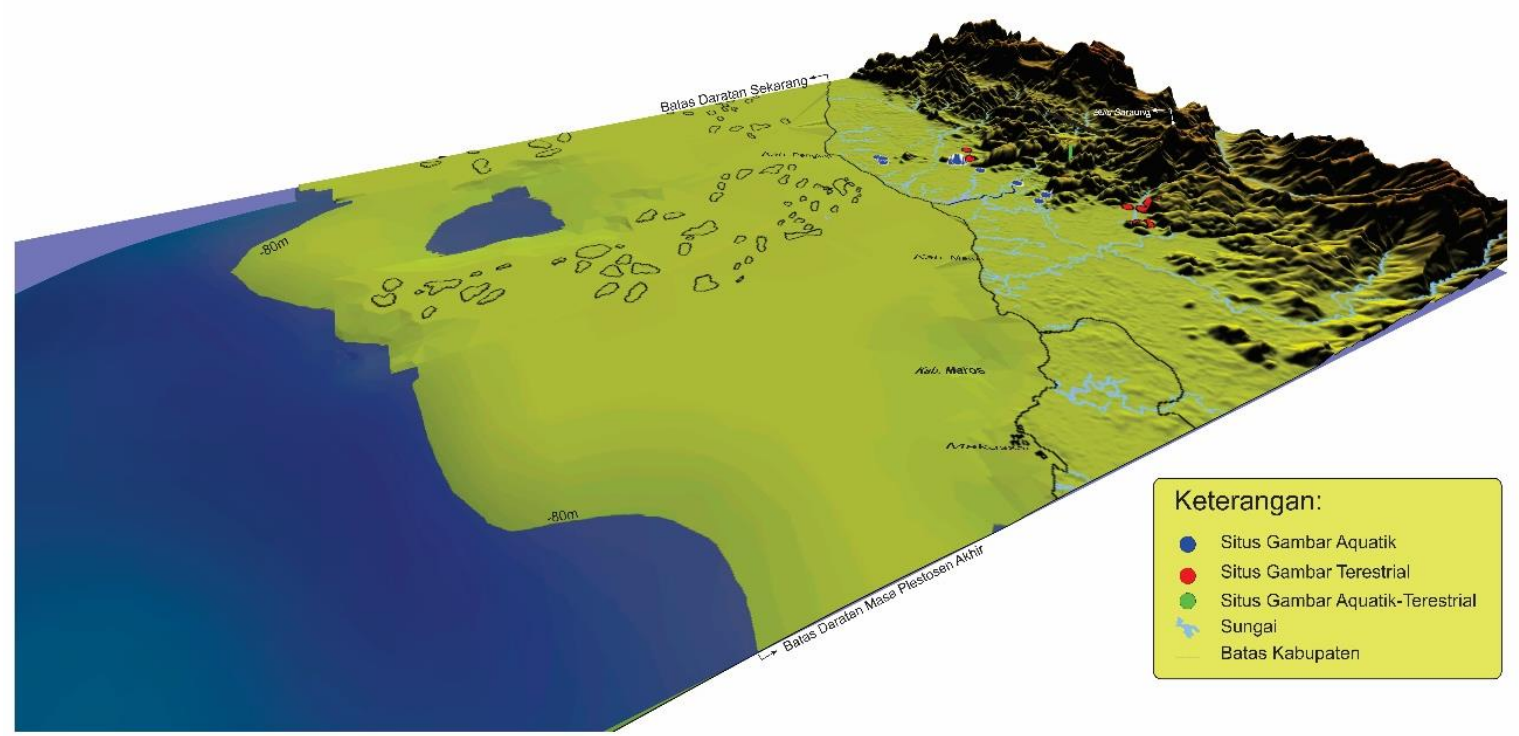

Gambar 13. Penurunan air laut pada masa Pleistosen Akhir, tampak dari arah barat daya (Sumber: BPCB Sul-Sel dan Peta Bathimetri skala 1: 250.000, DEM resolusi 1.5 arc second resolution, dimodifikasi oleh Basran Burhan, Tahun 2017)

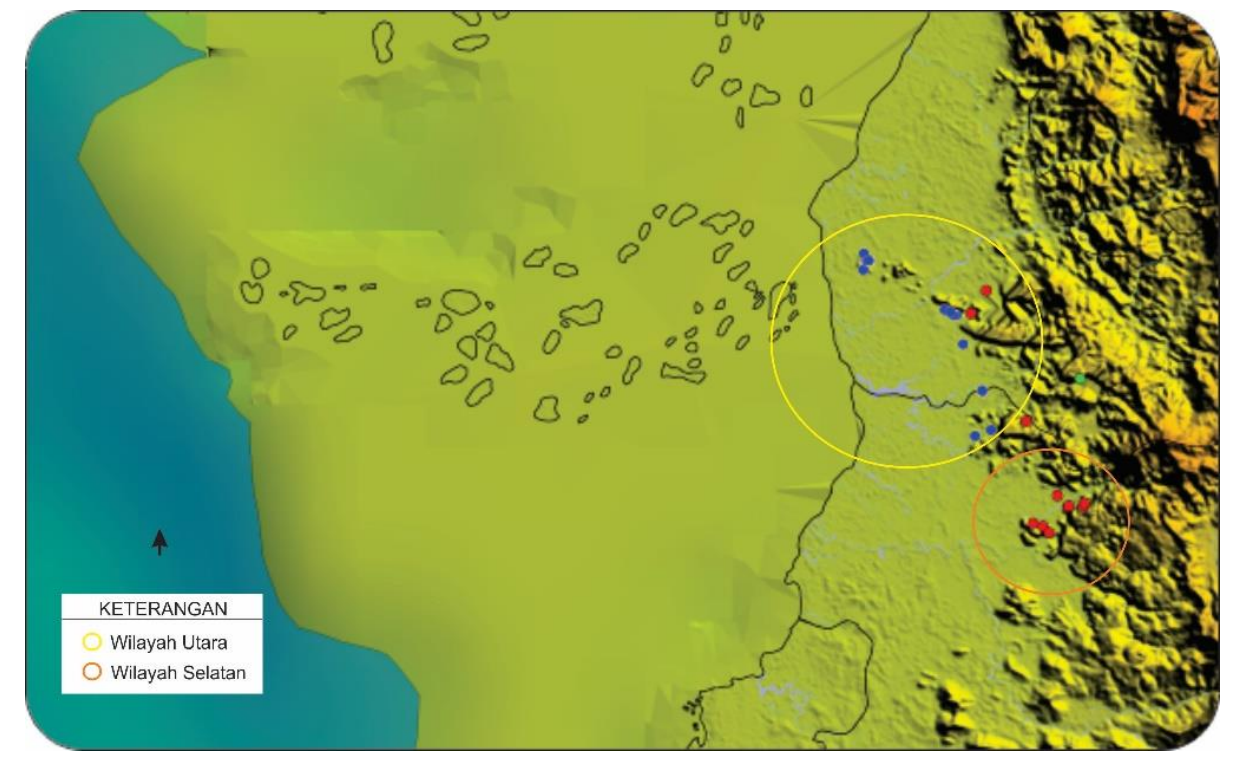

Gambar 14. Konsentrasi sebaran situs bergambar faun aquatik dan fauna terestrial, tampak dari atas (Sumber: BPCB Sul-Sel, Peta Bathimetri skala 1: 250.000 dan DEM resolusi 1.5 arc second resolution, dimodifikasi oleh Basran Burhan, Tahun 2017)

tersebut pulau-pulau Indo-Malaya merupakan wilayah hutan terbuka dan hutan hujan, tetapi pada masa ini diperkirakan terjadi juga musim kering yang panjang sehingga lingkungan pada saat itu adalah lingkungan savana (Stenis, 1961; Morley dan Flenley, 1987 dalam Bellwood, 2007). Mungkin karena pengaruh iklim tersebut kelompok budaya di wilayah selatan mengutamakan aktivitas perburuan hewan terestrial dengan beraktivitas pada dataran di sekitar gua dan area di sebelah timur gua-gua yang merupakan perbukitan kars yang memiliki celah yang datar serta lembahlembah di mana habitat hewan terestrial seperti babi dapat ditemukan. Tampaknya kondisi lingkungan pada saat kawasan kars diokupasi manusia di Pleistosen Akhir 
merupakan hutan hujan karena pada masa tersebut babi dan anoa cukup banyak ditemukan sebagai sisa makanan (Glover, 1975; Clason, 1989; Bulbeck, dkk., 2004), babi dan anoa merupakan habitat hewan dengan lingkungan hutan hujan tropis, hidup disekitar sungai dan kolam-kolam alami (Manansang, dkk., 1996). Oleh karena itu, melalui lukisan akhirnya ditemukan satu penjelasan bahwa manusia pada saat itu memiliki keterkaitan yang kuat dengan lingkungan hutan. Berbeda dengan situssitus di wilayah utara, meskipun sebagian situsnya berbatasan langsung dengan hutan tetapi mereka tidak menunjukkan hubungan dengan lingkungan hutan atau aktifitas penggambaran hewan terestrial.

\section{PENUTUP}

Sebaran lukisan gua di kawasan kars Sulawesi bagian selatan terbagi menjadi dua kelompok besar, yaitu sebaran di sebelah utara yang diwujudkan dengan simbol lukisan fauna aquatik dan sebaran di sebelah selatan yang diwujudkan dengan simbol lukisan terestrial. Selain perbedaan lokasional, yaitu utara dan selatan, perbedaan lainnya juga tampak pada pemilihan gua dengan karakter yang agak berbeda, yaitu gua aquatik di utara cenderung memilih gua pada gugusan kars kecil dan terluar, sedangkan gua terestrial cenderung memilih gua dengan gugusan kars besar-induk. Ciri-ciri tersebut merupakan ciri pembeda yang dapat dimaknai sebagai identitas. Penguatan identitas tersebut juga didukung dengan perbedaan pola keletakan lukisan telapak tangan, yaitu lukisan telapak tangan gua-gua di sebelah utara berada pada bagian dalam ruang gua, sedangkan keletakan lukisan telapak tangan pada gua-gua di wilayah selatan berada pada bagian luar ruang gua (Permana, 2008).
Ciri pembeda pada kelompok ini tidak hanya terbatas pada lukisan dan lanskap tetapi melalui dua aspek ini, ciri lainnya yang ditemukan adalah cara mereka menjalani kehidupan khususnya dalam subsistensi. Kehadiran lukisan perahu yang berasosiasi dengan lukisan fauna aquatik di situs Leang Batu Tianang (Syahdar, 2010; Pasaribu, 2016) menciptakan relasi terhadap aktifitas perairan, sedangkan di bagian selatan keberadaan tulang anoa dan babi sebagai hasil dari sisa makanan manusia pada masa 28,000 BP dan 31,000 BP menjelaskan hubungan dengan manusia yang berkaitan dengan aktivitas perburuan (Glover, 1975; Bulbeck, dkk., 2004). Disamping itu, sebaran lukisan di utara yang menampilkan karakter aquatik dan berasosiasi dengan lukisan antropomorfis serta bentuk geometrik yang berwarna hitam merupakan ciri dari budaya awal Austronesia (Aubert, dkk., 2014). Berdasar dari fenomena-fenomena tersebut kehadiran lukisan di kawasan kars bagian selatan Sulawesi merepresentasikan simbol lanskap sebagai identitas sosial di masa lalu yang merujuk pada identitas pelukis sebagai kelompok Austronesia di utara dan sebagai kelompok Pratoalean di selatan.

\section{UCAPAN TERIMA KASIH}

Ucapan terima kasih penulis haturkan kepada dosen pengasuh Lanskap arkeologi yang telah memperkenalkan pendekatan ini kepada penulis melalui kuliah di kampus UGM. Selanjutnya penulis mengucapkan terima kasih kepada Joshua Pasaribu dan Andi Sultra Handayani berkat karya tesis dan skripsi mereka berdua penulis sangat terbantu dalam membangun konsep tulisan ini. Terima kasih kepada BPCB Makassar yang telah membagikan data peta laporan, serta David McGahan atas foto lanskap di wilayah Leang-Leang. 


\section{DAFTAR PUSTAKA}

Ahimsa-Putra, H. S., 2013. Budaya Bangsa, Jati Ditri dan Integrasi Nasional: Sebuah Teori. Jejak Nusantara.

Aubert, M. et al., 2014. Pleistocene Cave Art From Sulawesi, Indonesia. Nature, Volume 514.

Bellwood, P., 2007. Prehistory of Indo-Malaysian Archipelago. Canberra: ANU E Press.

BTNBB, 2011. Identifikasi Keanekaragaman Jenis Mamalia di Taman Nasional Bantimurung Bulusaraung, Bantimurung: s.n.

Bulbeck, D., Sumantri, I. \& Hiscock, P., 2004. Leang Sakapao 1, a second dated Pleistocene Site from South Sulawesi, Indonesia. In: Quaternary Researc in Indonesia. London, UK: Taylor and Francis Group plc,.

Clason, A. T., 1989. Late Pleistocene / Holocene Hunters-Gatherers of Sulawesi. Paleohistoria, pp. 67-76.

Fuentes, O., 2017. The Social Dimension of Human Depiction in Magdalenian Rock Art (16,500 cal BP-12.000 cal BP): The Case of the Roc Aux-Sorciers Rock Shelter. Quaternary International, pp. 97-113.

Glover, I., 1975. Survey and Excavation in the Maros District, South Sulawesi, Indonesia, London: Intitute of Archaeology.

Gosden, C. \& Head, L., 1994. Landscape- A Usefull Ambiguous Concept. Aechaeology in Oceania, p. University of Sydney.

Handayani, A. S., 2015. Gambar Fauna Perairan Pada Gua-Gua Prasejarah Kawasan Kars Maros dan Pangkep. Makassar: Universitas Hasanuddin.

Kaelhofer, L., 2000. Creating Social Identity in The Landscape: Tidewater, Virginia, 16001750. In: Achaeology of Landscape. USA: Blackwell Publishers.

Knapp, B. \& Ashmore, W., 1999. Achaeological Landscape: Cinstrucet,Conceptualized, Ideational. In: Archaeology of Landscape. UK: Blackwell Publisher.

Kuster, H., 2004. Cultural Landscape. In: Cultural Landscape and Land Use. Dordrecht: Cluwer Academic Publisher.

Manansang, J. et al., 1996. Babyrusau: Populaton and Habitat Viability Assessment. Bogor: PHPA.

Pasaribu, Y. A., 2016. Konteks Budaya Motif Binatang Pada Seni Cadas Prasejarah Di Sulawesi Selatan. Depok: Universitas Indonesia. 
Permana, R. C. E., 2008. Pola Gambar Tangan Pada Gua-Gua Prasejarah Di Wilayah Pangkep-Maros Sulawesi Selatan, jakarta: s.n.

Pickering, M., 1994. The Physical Landscape as a Social Landscape: a Garawa Example. Archaeolgy in Oceania, pp. 149-161.

Ripoll, S. \& Munoz, F. J., 2007. The Paleolithic Rock Art of Crewell Ceags: Prelude to a Systematic Study. In: Paleolithic Cave Art at Creswell Ceags in European Context. New York: Oxford University Press.

Shanks, M. \& Tilley, C., 1992. Re-Constructing Archaeology: Theory and Practice. London and New York: Routledge.

Shanks, M. \& Tilley, C., 1987. Social Theory and Archaeology. USA: University of Mexico Press.

Syahdar, F. A., 2010. Gambar Cadas Perahu Pada Bidang Gua-Gua Prasejarah MarosPangkep. Makassar: Fakultas Sastra, Universitas Hasanuddin.

Terzi, M., 1992. Prehistory Rock Art. Chicago: Children Press Chicago. 